\title{
Evaluation of Correlation between Labour Productivity and Wages in Individual Countries' Economy
}

\author{
Irina Bogatyreva ${ }^{1, *}$, and Larisa Ilyukhina ${ }^{1}$ \\ ${ }^{1}$ Samara State University of Economics, 141, Soviet Army Str., 443090, Samara, Russia
}

\begin{abstract}
The paper is concerned with the problems of evaluating and managing the correlation between labour productivity growth and wages as the most important elements of strategic development of economies in different world countries. A judicious correlation between the growth rate of labour productivity and wages affects the reduction of production costs, increase of profitability, and improvement of production efficiency. This explains the relevance of the study to evaluate interconnection between labour productivity and wages in the digital economy. The authors presented the research results of the dynamics of labour productivity and wages for individual countries in real time of 2014-2018, calculated indicators of the correlation between growth rates of average wages in the countries' economy, described models, and developed the mechanism to manage the correlation between labour productivity and wages.
\end{abstract}

\section{Introduction}

The problem of the correlation between labour productivity growth and wages is an important economic issue. Trends of changes in labour productivity and wages reflect many aspects of production relations in any society. The economic sense of priority development of productivity in comparison with wages is that, on the one hand, it provides reduction in the cost per unit of wages for product output, which increases the share of surplus product to expand production and social needs, and on the other hand, it strengthens the material base of wage growth.

The point to regulate the correlation between labour productivity growth and wages under the conditions of the digital economy is becoming important for all countries. The possibility to expand reproduction, the balance in the consumer goods market, and the product coverage of growing financial incomes depend on its rational solution. In this regard, the research topic is extremely relevant.

The purposes of the study, the results of which are reflected in this paper, are to analyze and evaluate the correlation between labour productivity and wages at the cross-country level and develop the mechanism to manage it.

To achieve these goals, the following tasks were performed: analysis of the dynamics of labour productivity and wages in the context of individual countries was carried out, evaluation of indicators of the correlation between labour productivity and wages was

* Corresponding author: scorpiony70@mail.ru 
accomplished, the models were described, and the mechanism to manage the correlation between labour productivity and wages was developed.

\section{Literature review}

The scientific community and politicians of the leading world countries have been interested in the problem to identify the correlation between labour productivity and wages for a long period of time [1,2]. It has become particularly relevant today in the context of the digital economy development. Economic development in the modern world is based on the labour productivity growth. More than any other factors, it is labour productivity that determines the level and quality of life in the entire society, and it is the best indicator of economic well-being in the long term. The correlation between labour productivity and wages reflects the relation between production, distribution, and consumption. Therefore, the cost of the product produced by employees must be higher than the cost of products they consume. Without the implementation of this principle, it is impossible to constantly expand and improve production. Objective economic laws show that there is a direct correlation between labour productivity growth and wages [3]. According to the results of individual studies, this correlation is two-way [4].

Economic and managerial literature headlines the issue of the growth rate of labour productivity which is ahead of wages growth rate. It is impossible not to agree with the statements of some authors that the growth of labour productivity should be accompanied by a proportional increase in wages, since this affects an increase in profit and economic efficiency indicators [5]. However, in practice, the correlation between labour productivity and wages often weakens due to the influence of external factors on the growth of these indicators [6]. Such factors may include inefficient use and distribution of labour and capital [7], form of ownership, and size of exports [8]. The internal factors such as efficiency of working hours [9], digital technologies introduction, and effectiveness of labour rationing management also influence the optimal correlation between labour productivity growth and wages [10].

Thus, searching for the optimal correlation between the growth rate of labour productivity and wages is an important economic task.

\section{Methodology of research}

The theoretical and methodological basis of the study is the works of Russian and foreign scientists, devoted to the problems of managing labour productivity and wages. To achieve the purpose of the study, the authors used a statistical analysis method that includes statistical data comparison and collating from a group of countries. The empirical base of the study is official statistics on the foreign countries' economy and statistical materials on the Russian economy.

Data collection monitoring and study of statistical information on the dynamics of labour productivity and wages in the individual countries' economy allowed the authors to obtain reliable results of the study and formulate reasonable conclusions.

Analysis and evaluation of the correlation between labour productivity and wages involves the study of the test indicators dynamics, which is characterized by the rates of their growth and increment. The calculated labour productivity indicator represents the volume of gross domestic product per one person employed in the country's economy.

For the purpose to study the correlation of labour productivity and wages in detail, the following indicators were calculated: the coefficient of own-product real wage and the outdistancing coefficient of average annual wages. The analysis is based on the algorithm 
to calculate the correlation between the growth rate of labour productivity and wages, which is shown in figure 1.

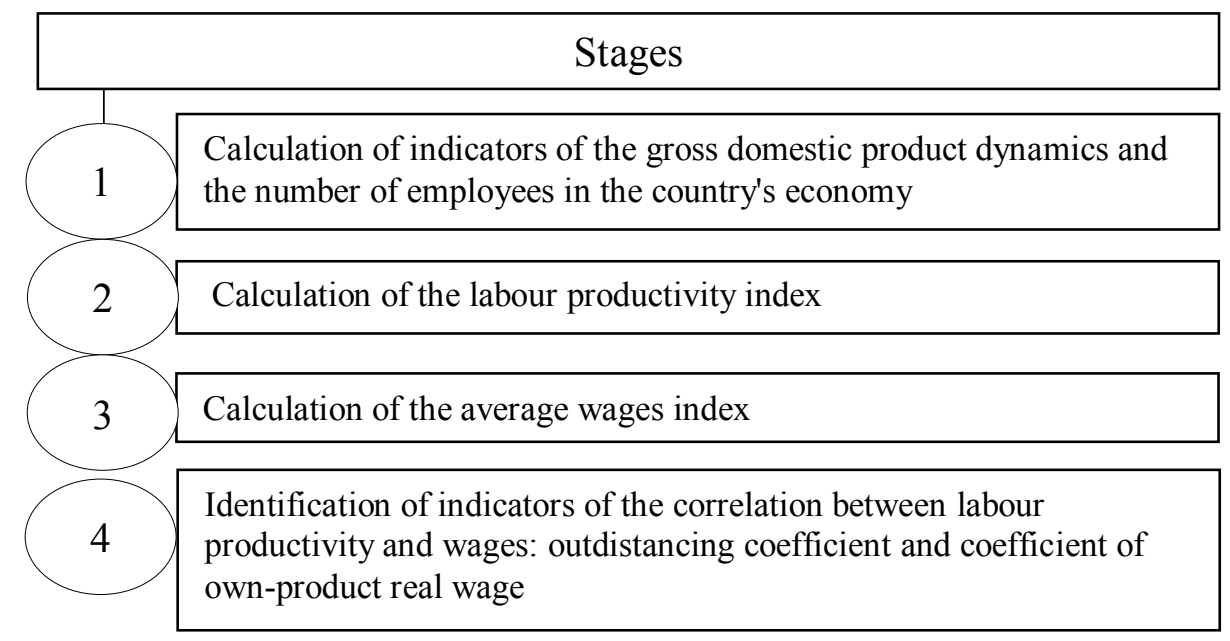

Fig. 1. Algorithm to calculate the correlation between labour productivity and wages

\section{Practical significance, suggestions and the results of realization, the results of experimental research}

\subsection{Comparative analysis of the dynamics of labour productivity and wages in the economy of the Russian Federation and foreign countries}

The study object of the correlation of labour productivity and wages was Russia and some economically developed countries: Denmark, France, Norway, US, Italy, Sweden, and UK. Opportunities for growth in labour productivity and wages are determined by high level of economic and social development of the country, quality of labour resources, developed production infrastructure, and industry-specific diversity.

The study of trends of labour productivity and wages growth in the economy of Russia and 7 foreign countries covering a five-year period of time allows the authors to identify the expansion and contraction in these key indicators dynamics. The calculations have shown that labour productivity in the countries under study has a positive trend in the period under review. However, over the last years, the growth rate of this indicator has decreased due to a decrease in the labour power and the volume of gross domestic product (Table 1). 
Table 1. Labour productivity and wages in the economy of Russia and foreign countries in 2014-2018, \%

\begin{tabular}{|c|c|c|c|c|c|c|}
\hline Indicators & 2014 & 2015 & 2016 & 2017 & 2018 & 2018 to 2014 \\
\hline \multicolumn{7}{|c|}{ Denmark } \\
\hline Gross domestic product & 101.6 & 102.3 & 103.3 & 102.0 & 102.4 & 112.1 \\
\hline $\begin{array}{l}\text { Number of employed in the } \\
\text { economy }\end{array}$ & 100.9 & 101.4 & 101.7 & 101.6 & 101.4 & 107.2 \\
\hline Labour productivity & 100.7 & 100.9 & 101.5 & 100.4 & 101.0 & 104.6 \\
\hline Average annual wages & 102.5 & 102.1 & 102.0 & 100.7 & 101.9 & 109.5 \\
\hline \multicolumn{7}{|c|}{ France } \\
\hline Gross domestic product & 100.9 & 101.1 & 101.0 & 102.3 & 101.7 & 107.2 \\
\hline $\begin{array}{l}\text { Number of employed in the } \\
\text { economy }\end{array}$ & 100.5 & 100.2 & 100.6 & 101.0 & 101.0 & 103.3 \\
\hline Labour productivity & 100.4 & 100.9 & 100.4 & 101.2 & 100.7 & 103.6 \\
\hline Average annual wages & 100.8 & 101.3 & 101.0 & 101.8 & 101.7 & 106.8 \\
\hline \multicolumn{7}{|c|}{ Italy } \\
\hline Gross domestic product & 99.9 & 100.7 & 101.3 & 101.7 & 100.8 & 104.5 \\
\hline $\begin{array}{l}\text { Number of employed in the } \\
\text { economy }\end{array}$ & 100.0 & 100.6 & 101.3 & 101.2 & 100.9 & 104.0 \\
\hline Labour productivity & 99.9 & 100.1 & 99.9 & 100.5 & 99.9 & 100.3 \\
\hline Average annual wages & 100.6 & 101.0 & 100.9 & 100.1 & 101.2 & 103.8 \\
\hline \multicolumn{7}{|c|}{ Norway } \\
\hline Gross domestic product & 102.0 & 102.0 & 101.1 & 102.3 & 101.3 & 109.0 \\
\hline $\begin{array}{l}\text { Number of employed in the } \\
\text { economy }\end{array}$ & 101.0 & 100.5 & 100.3 & 101.2 & 101.6 & 104.7 \\
\hline Labour productivity & 100.9 & 101.5 & 100.8 & 100.8 & 99.6 & 103.6 \\
\hline Average annual wages & 102.8 & 102.9 & 101.4 & 102.4 & 103.2 & 113.3 \\
\hline \multicolumn{7}{|c|}{ UK } \\
\hline Gross domestic product & 102.6 & 102.3 & 101.9 & 101.9 & 101.4 & 110.5 \\
\hline $\begin{array}{l}\text { Number of employed in the } \\
\text { economy }\end{array}$ & 102.4 & 101.7 & 101.5 & 101.0 & 101.2 & 108.0 \\
\hline Labour productivity & 100.2 & 100.6 & 100.4 & 100.9 & 100.2 & 102.3 \\
\hline Average annual wages & 101.1 & 101.3 & 102.2 & 102.4 & 102.7 & 110.0 \\
\hline \multicolumn{7}{|c|}{ Sweden } \\
\hline Gross domestic product & 102.7 & 104.4 & 102.4 & 102.4 & 102.2 & 114.9 \\
\hline $\begin{array}{l}\text { Number of employed in the } \\
\text { economy }\end{array}$ & 101.4 & 101.5 & 101.8 & 102.4 & 101.6 & 109.0 \\
\hline Labour productivity & 101.3 & 102.9 & 100.6 & 99.9 & 100.6 & 105.4 \\
\hline Average annual wages & 102.1 & 102.6 & 102.4 & 102.3 & 102.8 & 112.8 \\
\hline \multicolumn{7}{|c|}{ US } \\
\hline Gross domestic product & 102.5 & 102.9 & 101.6 & 102.9 & 103.1 & 112.9 \\
\hline $\begin{array}{l}\text { Number of employed in the } \\
\text { economy }\end{array}$ & 101.6 & 101.7 & 101.7 & 101.2 & 101.6 & 108.0 \\
\hline Labour productivity & 100.9 & 101.2 & 99.9 & 101.1 & 101.3 & 104.5 \\
\hline Average annual wages & 102.9 & 102.7 & 101.1 & 102.7 & 102.6 & 112.6 \\
\hline \multicolumn{7}{|c|}{ Russia } \\
\hline Gross domestic product & 100.7 & 97.7 & 100.3 & 101.6 & 102.2 & 102.5 \\
\hline $\begin{array}{l}\text { Number of employed in the } \\
\text { economy }\end{array}$ & 100.2 & 101.1 & 100.0 & 99.6 & 105.0 & 105.9 \\
\hline Labour productivity & 100.5 & 96.6 & 100.2 & 102.0 & 101.7 & 100.9 \\
\hline Average annual wages & 109.0 & 104.7 & 107.9 & 106.7 & 111.6 & 146.6 \\
\hline
\end{tabular}

Source: compiled by the authors

The main factors of heterogeneous dynamics of labour productivity growth in many countries are: weak innovative activity of enterprises, decrease in the share of new technologies implementation into production, reduction in financing of scientific and innovative development, and inefficient use of all types of resources [11]. On the other hand, it is necessary to take into account the strong influence of wage dynamics on labour productivity changes. These two indicators are interrelated: the main source of productivity 
growth is the increase in wages, and vice versa, the average wages actively affect the level of output. Therefore, special attention of the study is aimed at evaluating the level and dynamics of wages, which are one of the main sources of income for the economically active population of all countries. For example, in the Russian Federation, the share of wages in the incomes of people is about $65-70 \%$.

The results of the analysis have shown an increase in the growth rate of wages in all the countries studied, but in different proportions: the minimum increase in wages over a five year period was found in Italy (3.8\%), and the maximum increase was in Russia $(46.6 \%)$. Thus, wage growth has significantly outpaced productivity growth in all countries over a long period of time.

The calculations have shown that the same situation is observed in Russia: in 20142018 , with an increase in the country labour productivity by $0.9 \%$, the average wages increased by 1.46 times (Fig. 2).

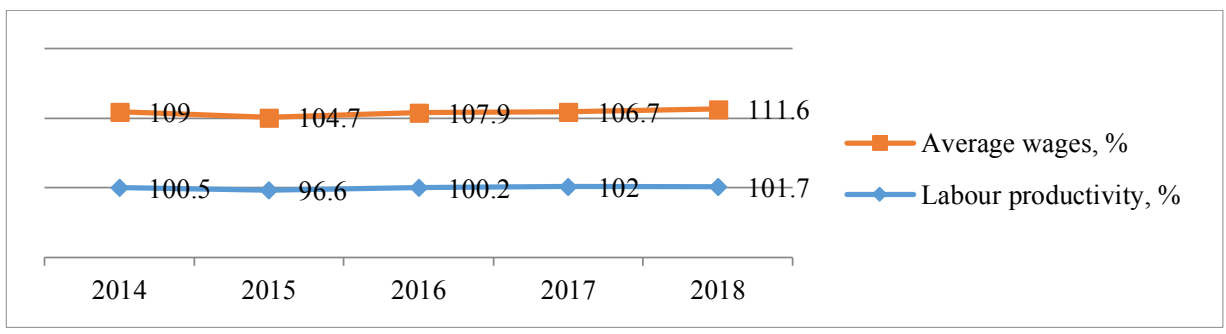

Fig. 2. Dynamics of labour productivity and wages in the Russian economy in $2014-2018$

\subsection{Correlation between the growth rate of labour productivity and wages un the economy of Russia and foreign countries}

An important macroeconomic proportion that allows to evaluate the level of economic well-being in a particular economic system is the correlation between the growth rate of labour productivity and wages. Since the correlation between the growth rates of labour productivity and average wages is a relative indicator, the coefficients obtained from statistical calculations can be used for international comparison. To analyze different countries, the indicators of outdistancing and own-product real wage were calculated (Table 2).

Table 2 shows that average wages are growing faster than labour productivity in all countries. The homogeneous dynamics of the outdistancing coefficient and the coefficient of own-product real wages from a group of countries was observed over the five-year period except for Russia (Fig. 3). The coefficient of own-product real wage in seven countries in $2014-2018$ increased by an average of 1.06 times, while the outdistancing coefficient did not exceed $100 \%$. The reasons for this situation are inflationary processes in the countries' economy, excess demand for labour, and price increase for goods and services. Consequently, it is assumed that the countries' economy is focused on an inflationary model to manage the correlation between labour productivity and wages. This leads to non-compliance with the fundamental principle of payroll management to ensure faster growth rates of labour productivity and production efficiency over the growth rate of wages. 
Table 2. Calculation of the ratios of labour productivity and wages in the economy of the Russian Federation and foreign countries in 2014-2018, \%.

\begin{tabular}{|c|c|c|c|c|c|c|}
\hline Indicators & Countries & 2014 & 2015 & 2016 & 2017 & 2018 \\
\hline \multirow{4}{*}{$\begin{array}{c}\text { Outdistancing } \\
\text { coefficient }\end{array}$} & Denmark & 98.2 & 98.8 & 99.5 & 99.7 & 99.1 \\
\cline { 2 - 7 } & France & 99.6 & 99.6 & 99.4 & 99.4 & 99.0 \\
\cline { 2 - 7 } & Italy & 99.3 & 99.1 & 99.0 & 100.4 & 98.7 \\
\cline { 2 - 7 } & Norway & 98.1 & 98.6 & 99.4 & 98.4 & 96.5 \\
\cline { 2 - 7 } & UK & 99.1 & 99.3 & 98.2 & 98.5 & 97.6 \\
\cline { 2 - 7 } & Sweden & 99.2 & 100.3 & 98.2 & 97.6 & 97.8 \\
\cline { 2 - 7 } & US & 98.0 & 98.5 & 98.8 & 98.4 & 98.7 \\
\cline { 2 - 7 } own-product real & Russia & 92.2 & 92.2 & 92.8 & 95.6 & 91.1 \\
\cline { 2 - 7 } wage & Denmark & 101.9 & 101.2 & 100.5 & 100.3 & 100.9 \\
\cline { 2 - 6 } & France & 100.4 & 100.4 & 100.6 & 100.6 & 101.0 \\
\cline { 2 - 6 } & Italy & 100.7 & 100.9 & 101.0 & 99.6 & 101.3 \\
\cline { 2 - 6 } & Norway & 101.9 & 101.4 & 100.6 & 101.6 & 103.6 \\
\cline { 2 - 6 } & UK & 100.9 & 100.7 & 101.8 & 101.5 & 102.4 \\
\cline { 2 - 6 } & Sweden & 100.8 & 99.7 & 101.8 & 102.4 & 102.2 \\
\cline { 2 - 6 } & US & 102.0 & 101.5 & 101.2 & 101.6 & 101.3 \\
\cline { 2 - 6 } & Russia & 108.4 & 108.4 & 107.7 & 104.6 & 109.8 \\
\hline
\end{tabular}

Source: compiled by the authors

Indicators of the correlation between labour productivity and wages in 2014-2018

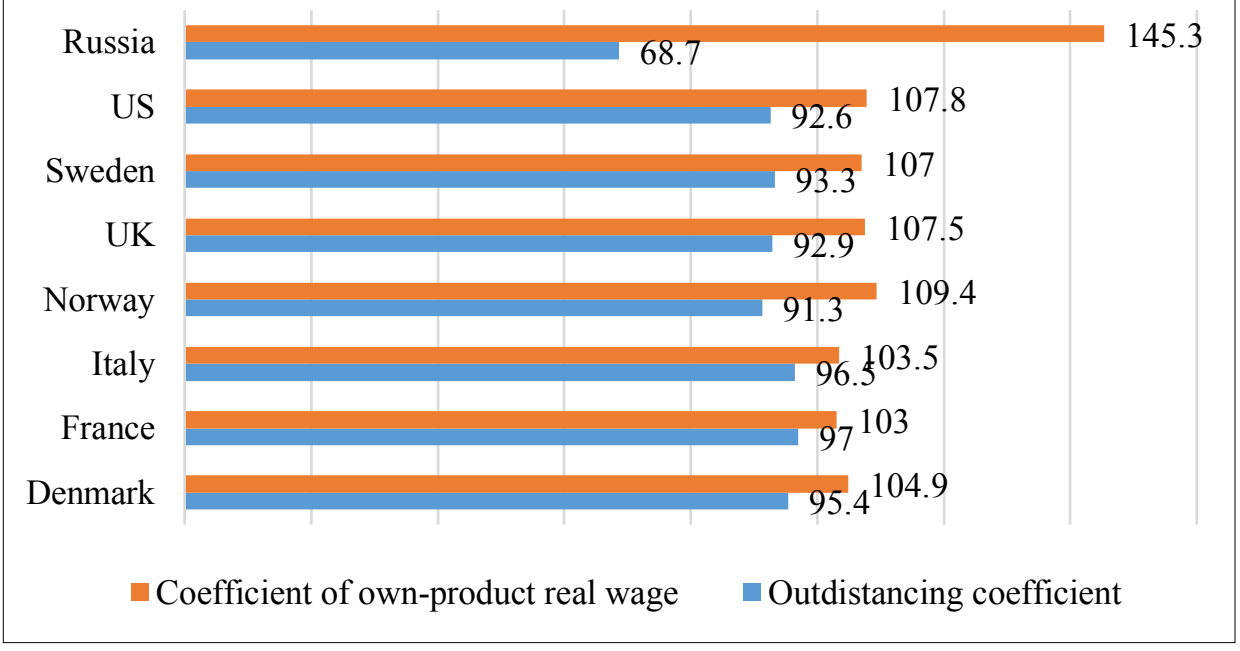

Fig. 3. Dynamics of ratio indicators of labour productivity and wages in the countries' economy in $2014-2018$

The opposite situation was observed in Russia, where the outdistancing coefficient (68.7\%) was consistently low, and the coefficient of own-product real wage (145.3\%) was high.

The analysis of indicators of the correlation between labour productivity and wages has shown that the change in unit costs of wages per unit volume of production throughout period under review remains quite high (from $104.6 \%$ in 2017 to $109.8 \%$ in 2018). This is 
ultimately reflected in the product cost.

For extended reproduction, profit taking, and profitable production, it is necessary that wage growth should depend on labour productivity increase in a direct proportion. It is possible with the use of the classical model of labour productivity and wage management.

\subsection{Models and mechanism to manage the correlation between labour productivity and wages}

Three models of the correlation between labour productivity growth and wages have become the most famous in world practice:

- classical model assumes a direct proportional dependence of wages on labour productivity ( $10 \%$ increase in labour productivity leads to $10 \%$ increase in wages),

- inflation model is based on faster wage growth over labour productivity (wages are growing faster than labour productivity),

- incentive model which supports the lag of wages growth in comparison with labour productivity growth.

The classical model of the correlation between labour productivity and wages is the most acceptable for the economic development, but it is extremely rare in practice. According to the results of the research, the world economy is based on the inflation model of the correlation between labour productivity and wages. This fact leads to the following negative consequences: lack of the interrelation between labour costs and labour remuneration, discouragement of labour productivity increase, decrease in the purchasing power of wages, etc. The authors developed the mechanism to manage the correlation between labour productivity and wages, which includes 4 stages (Fig. 4).

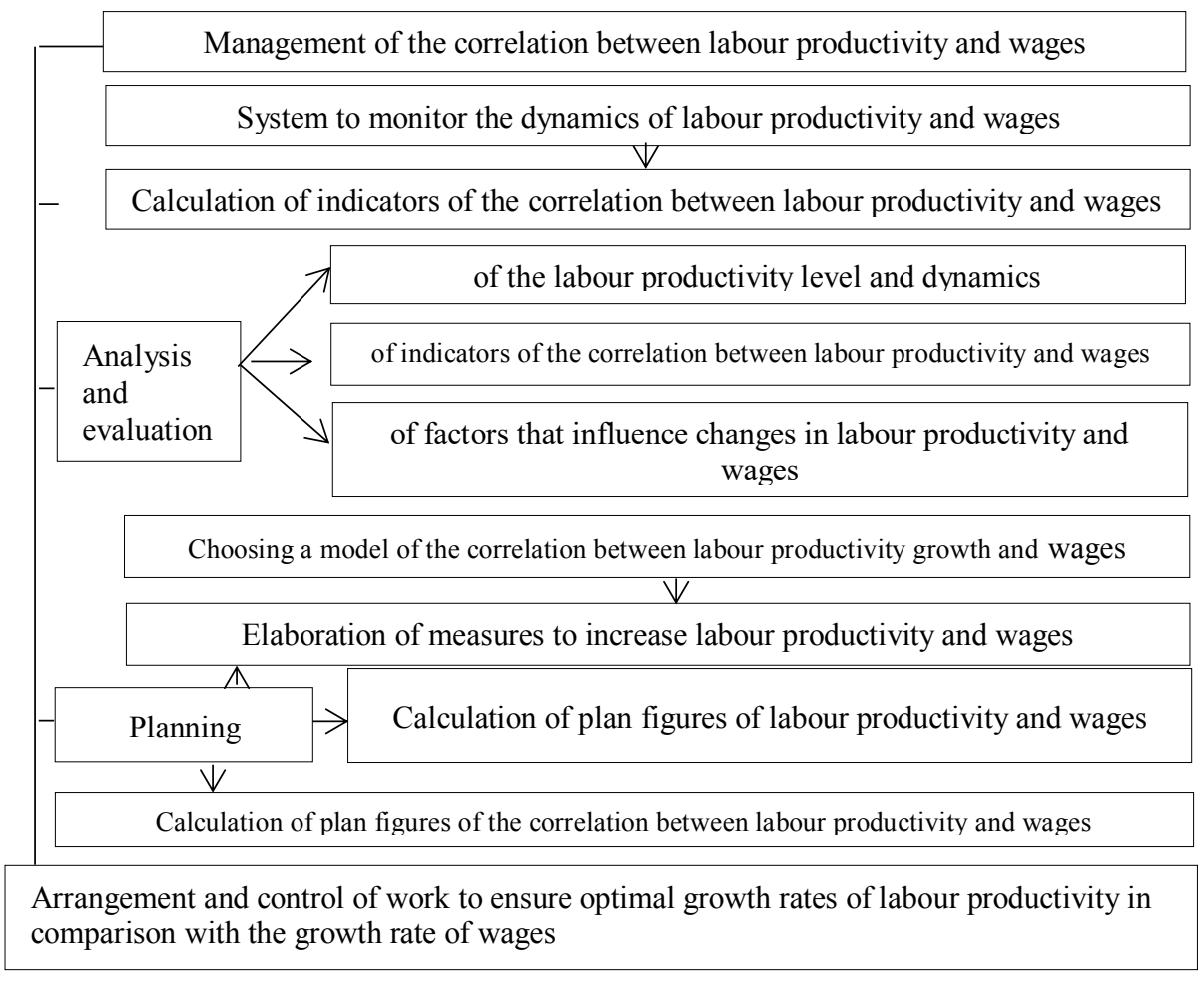

Fig.4. Mechanism to manage the correlation between labour productivity and wages 


\section{Conclusions}

Ensuring the optimal level of labour productivity and wages is one of the primary tasks of different countries' economy today. The main directions to increase the labour productivity level and achieve the optimal correlation between labour productivity growth and wages are: reducing the cost of financial resources, improving product competitiveness, decreasing the credit and tax burden, increasing the level of innovation implementation, increasing demand by stimulating the purchasing power of consumers, strengthening employee labour activity, and introducing scientifically based payroll management at enterprises.

The following issues are actively discussed in scientific circles: whether there is a close correlation between labour productivity and wages [12], what correlation between labour productivity and wages should be considered optimal, what model of the correlation between labour productivity and wages is optimal for the further development of different countries' economy, what factors affect the growth of labour productivity and wages [13], and how to manage effectively the growth and correlation between labour productivity and wages. The results of this study make a scientific contribution to resolve the problems of choosing the model for the correlation between labour productivity and wages and to develop the mechanism to manage it.

\section{References}

1. J. Pehkonen, European Economic Review. 39 (6), 1181-1196 DOI:10.1016/0014-2921(94)00017-T

2. H. Bester, E. Petrakis. International Journal of Industrial Organization. 22 (1), 83-100 (2004) DOI: 10.1016/S0167-7187(03)00093-6

3. R. Riley, C. Rosazza Bondibene. Labour Economics. 44, 27-50 (2017) DOI: $10.1016 /$ j.labeco.2016.11.010

4. M. Millea, S.M. Fues. The Quarterly Review of Economics and Finance. 45 (45), 796-807 (2005) DOI: 10.1016/j.qref.2004.06.004

5. A.V. Kovalenko, E.S. Kalinskaya, I.V. Geleta. Sustainable Development Economics. 3 (19), 99-104 (2014)

6. M. Fafchamps, S.E. Hamine. Research in Economics. 71 (2), 291-305) (2017) DOI: $10.1016 /$ j.rie.2016.12.003

7. K. Nakamura, S. Kaihatsu, T.Yagi. Economic analysis and police. 62, 57-79 (2019) DOI: $10.1016 /$ j.eap.2018.11.002

8. J. Zhang, X. Liu. Economic Systems. $37 \quad$ (3), $354-368$ (2013) DOI: 10.1016/j.ecosys.2013.05.001

9. I.V. Bogatyreva, L.A. Ilyukhina, M.V. Simonova and N.V. Kozhukhova. SHS Web of Conferences. 62 (06002), (2019) DOI:10.1051/shsconf/20196206002

10. V.A. Schekoldin, I.V. Bogatyreva, L.A. Ilyukhina, V.M. Kornev. Helix. 8(5), 36153628 (2018) DOI: 10.29042/2018-3615-3628

11. Bogatyreva, M. Simonova, E. Privorotskaya. E3S Web of Conferences. 91 (08022) (2019) DOI: 10.1051/e3sconf/20199108022

12. A.A. Popkov. Economic Sciences. 4, 61-64 (2015)

13. V.V. Aranzhin. Labor Economics. 6(1), 523-534 (2019) DOI: 10.18334/et.6.1.39938 